\title{
Improvement of Student Creative Thinking Skills Through Implementation of OrDeP2E Learning Model with Contextual Approach
}

\author{
Hamsa Doa \\ Postgraduate Study Program of Science Education, Universitas Negeri Surabaya, Surabaya, Indonesia \\ hamsadoa29@gmail.com \\ Budi Jatmiko, Thamrin Hidayat \\ Postgraduate Study Program of Science Education, Universitas Negeri Surabaya, Surabaya, Indonesia \\ budijatmiko@unesa.ac.id,pmksthamrin@gmail.com \\ Binar Kurnia Prahani \\ Department of Islamic Primary Teacher Education, Faculty of Tarbiyah and Teacher, UIN Sunan Ampel Surabaya, Surabaya, \\ Indonesia \\ binarprahani@gmail.com
}

\begin{abstract}
The OrDeP2E learning model based on contextual approach is a science-based learning activity of contextual approach that emphasizes the creative thinking process of junior high school students. The syntaxes of OrDeP2E learning model are (1) Problem definition, (2) Problem Orientation, (3) Submission of Hypothesis, (4) Hypothesis Testing, and (5) Evaluation. The objective of this research is to improve students' creative thinking skill through the implementation of OrDeP2E learning model based contextual approach. This study used one group pre-test and post-test design for 64 students of Public junior high school in Sidoarjo, Indonesia. Student creative thinking skills are measured using the Creative Thinking Skills Assessment Sheet (CTSAS). Paired t-test, n-gain and Anova test are used as the data analysis technique. The result of the research showed that (1) The mean post-test value is 84 (high category); (2) There is improvement of students' creative thinking skill with $\alpha=5 \%$; (3) the average score of $n$-gain's students creative thinking skill is 0.77 (high category); (4) There is no difference (no consistency) n-gain's students creative thinking skills in all groups, and (5) Students respond very positively to the implementation of the OrDeP2E learning model based on contextual approach. Therefore, the OrDeP2E learning model based on contextual approach has proven as an effective way to improve creative thinking skill of junior high school students. The implication of this research is OrDeP2E learning model based on contextual approach could be used as a solution to improve the creative thinking skill of junior high school students.
\end{abstract}

Keywords- Model OrDeP2E, contextual approach, creative thinking skill

\section{INTRODUCTION}

Education is a conscious and effort to create an atmosphere of learning process to construct students' behaviour and contribute their potential to have a religious spiritual, selfcontrol, personality, intelligence, noble character, healthy, independent, creative and capability for being a responsible citizen [1]. Therefore, the role of education is very important to prepare qualified students. A quality students are defined to be able to compete in the era of globalization, where full of challenges and competition. Thus, It is very urgent to prepare students capability such as a meaningful quality learning to compete and face the challenges of 21 st century, creative thinking skills is the art of Quality learning. Creative thinking skills are mental activities to develop or discover new, aesthetic, constructive ideas that are directly related to conceptual views and to suppress the aspect of intuitive and rational thinking [2]. Learning natural science is an active process that students must do in the first lace, rather than being a viewer of it. In science learning, students observe the object of an event, ask questions, gain knowledge, compose an explanation of natural phenomena, test the explanation in different ways and try to communicate it with the other recipients. Therefore, science learning is more emphasizing on learning directly through scientific attitude. Scientific attitudes or behaviours are analysis, ask questions and decision making [1]. In the process of scientific attitude, creative thinking skills of students are required in conducting investigations, asking questions, and making decisions. The Indicators of creative thinking skills in natural science are deep thinking, flexibility, originality, and elaboration (thinking) [3].

Based on preliminary study conducted at SMPN 1 Krian, those four indicators of creative thinking skills are still defined in a low rank. Because the teachers have not fully involved in teaching creative thinking maximally and assuming students' ability only by measuring cognitive course and only providing only a single cut answer that are not relating them to the real life. Based on these conditions, the teacher must know and master the principles of learning tools and learning models used in teaching and learning activities in the class [4]. The principle 
of learning is expected to be more emphasizing on the emergence of multidimensional answers, which involves student's creative thinking skills in the learning process takes place. In addition, the importance of creative thinking to the students is able to find multidimensional answers, develop individual creativity students such as a comfortable atmosphere in learning, feel the flow of diversity and develop new skills. Creative thinking could also train the difficulties in creative thinking such as fear of failure, lack of confidence, thinking difficulties, lack of intrinsic motivation and too much extrinsic motivation and low tolerance for ambiguity [5].

One of the learning models that involves and train students in the learning process to think creatively and actively is the OrDeP2E learning model (Problem Orientation, Problem Definition, Hypothesis Enhancement, Hypothesis Testing, and Evaluating or Follow Up) with contextual approach. There are 4 strategic contextual approaches: (1) Contextual Teaching Learning (CTL) is a learning model that emphasizes the full learner's activity both physically and mentally, (2) CTL sees that learning is not memorizing, but the process is experiencing in real life, (3) class in learning CTL is not a place to obtain information, but a place to test the data of their findings (4) learning materials are found by students themselves, not a giving from others [6]. The learning process of OrDeP2E with a contextual approach, the students are actively involved in teaching and learning activities in class and also solving problems that are often found in their daily life. The OrDeP2E learning is also well targeted in material that includes information, concepts, ways of thinking, and values. Thus, students could also learn and try to recall their experience [7]. According to previous research [1], OrDeP2E learning model is suitable to be applied in junior high school students because according to Piaget [8] 12 to 14 years old children are stating into a concrete operational stage that still needs a concrete object in their learning process. The of Application learning model OrDeP2E [1] is able to improve creative thinking. In addition, this study is supported by research conducted by [12] which stated that learning with contextual approach could improve students' creative thinking. The focus of this study is a follow-up study based on $[1,9]$ recommendations to see the effectiveness of the OrDeP2E learning model with contextual approaches in improving students' creative thinking skills. The results of this study are expected to be an empirical evidence of the effectiveness of OrDeP2E learning model with a contextual approach in improving students' creative thinking skills in natural science lessons.

\section{EXPERIMENTAL METHOD}

\section{A. General Background of Research}

This research was conducted at SMPN 1 Krian (Sidoarjo, Indonesia). The subject is eight grade students of science subject year 2017/2018. The objective is to analyse the effectiveness of OrDP2E learning model with contextual approach in improving students' creative thinking skill before and after using OrDP2E learning model with contextual approach. The effectiveness of the OrDP2E learning model with contextual approach is determined by: 1) Significant increase (statistically) on score between pre-test and post-test of students' creative thinking skill; 2) The average of n-gain determined at least on the low improvement criteria; and 3) The consistency of an average score of $n$-gain of creative thinking skills.

\section{B. Sample of Research}

The samples of research were 64 students at SMPN 1 Krian using purposive sampling technique; which is in the two groups; group-1 (class VIIID) and group-2 (class VIIIE) with homogeny of creative thinking skills. Each group consists of students of science subject.

\section{Instrument and Procedures}

The students' creative thinking skills are measured using the Creative Thinking Skills Assessment Sheet (CTSAS), which has been declared valid and reliable [10]. CTSAS is structured based on these indicators; 1) fluency thinking; 2) flexibility, 3) originality; and 4) elaboration [3]. The subjects of science lesson to be used in this study were selected in accordance with the characteristics of the OrDP2E learning model with a contextual approach. This study used one group pre-test posttest design, $\mathrm{O} 1 \mathrm{X} \mathrm{O} 2$ [14]. The first step of the learning is begun by giving pre-test (O1). Every elementary school student is required to complete CTSAS. After the pre-test, the teacher applied OrDP2E learning model with contextual approach and science learning tool in each group $(\mathrm{X})$. The Implementation of OrDP2E learning model with a contextual approach has been conducted for four meetings on science subjects. The learning of science using the OrDP2E learning model has five syntaxes: 1) problem orientation, 2) problem definition, 3) hypothesis submission, 4) hypothesis testing, and 5) evaluation. Natural science learning tools consist of: syllabus, learning implementation plan, student activity sheet, textbook, CTSSAS, and student response questionnaire (valid and reliable). Each phase of the OrDP2E learning model with a contextual approach were trained the indicators of creative thinking skills; 1) fluency thinking 2) flexibility, 3) originality and 4) elaboration [3]. The implementation of the OrDP2E learning model with the contextual approach ends with post-test (O2) using CTSAS. Every student is required to complete CTSSAS post-test.

\section{Data Analysis}

The students' creative thinking skills were analysed based on pre-test and post-test assessments using the OrDP2E learning model with a contextual approach. Pre-test, post-test, and n-gain data of students' creative thinking skills were analysed using inferential statistics with the help of SPSS software. $\mathrm{N}$-gain is determined using the equation: $\mathrm{n}$-gain = (post-test score - pre-test) / (maximum score - pre-test score) [14], with criteria: (1) if n-gain $\geq .7$ (high), (2) if .3< $<$-gain $<.7$ (moderate), and (3) if n-gain $\leq .3$ (low). The choice of statistical testing methods depends on the assumption of normality and 
homogeneity of variants for pre-test, post-test, and n-gain scores. Inferential statistical test with paired test or Wilcoxon test (analysis of statistical improvement), n-gain consistency analysis of all groups of junior high school students after using OrDP2E learning model with contextual approach using Anova or Kruskal-Walls test and Student responses were analyzed by quantitative descriptive by calculating the percentage of statements given [31]

\section{RESULT AND DISCUSSION}

The results are presented in Table I, Table II, Table III, Table IV, and Figure 1 as follows.

TABLE I: THE AVERAGE SCORE OF PRE-TEST, POST-TEST AND NGAIN CREATIVE THINKING SKILLS OF JUNIOR HIGH SCHOOL STUDENTS.

\begin{tabular}{|c|c|c|c|c|c|c|}
\hline \multirow{2}{*}{ Group } & \multicolumn{4}{|c|}{ Creative thinking skills of junior high school students } \\
\cline { 2 - 7 } & \multicolumn{2}{|c|}{ Pre-test } & \multicolumn{2}{c|}{ Post-test } & \multicolumn{2}{c|}{ N-gain } \\
\hline $\begin{array}{c}\text { 1. (Class } \\
\text { VIIID) }\end{array}$ & 30.5 & Low & 84.4 & High & 0.78 & High \\
\hline $\begin{array}{c}\text { 2. (Class } \\
\text { VIIIE) }\end{array}$ & 28.3 & Low & 83.9 & High & 0.77 & High \\
\hline
\end{tabular}

Table I described the mean value of pre-test, post-test and n-gain creative thinking skills of junior high school students. The low pre-test value is due to the students unfamiliar with OrDeP2E learning model with contextual approach, because their teachers did not show it. According to Piaget's theory, any student of any age is actively involved in the process of obtaining information and interpretation in their own knowledge. Good pedagogy involves students with their own situations in doing their experiments. The broad meaning of the phrase is to try everything in order to seek what happening, the manipulation of things, the manipulation of symbols, to ask questions and tries to find answers by themselves, matches what is found at a time with what is found at other times, and comparing its findings with the findings of other students [8]. Based on Piaget's theory, students 'interest in natural science subject of OrDeP2E model with contextual approach could increase students' creative thinking skill which is known through n-gain Class VIIID and Class VIIIE that is considered as high category, which means the increase of pre-test and posttest value at both are categorized as high rank. The results of this study proved that the implementation of OrDP2E learning model with contextual approach proven to effectively improve the skills of creative thinking skills of junior high school students. OrDeP2E learning model with developed contextual approach has validity (content and construct), practicality, and effectiveness. Normality test results and homogeneity of variance suggest that the pre-test, post-test, and n-gain scores of students' creative thinking skills are homogeneous and normally distributed for the whole group. Therefore, the impact of the implementation of the OrDP2E learning model with a contextual approach in improving students' creative thinking skills for the whole group is using Paired t-test and consistency test using Independent t-test. Paired t-test and Independent ttest results are presented in Table II and Table III.
TABLE II: THE RESULTS OF PAIRED T-TEST OF CREATIVE THINKING SKILLS IN ALL GROUPS.

\begin{tabular}{|c|c|c|c|c|c|}
\hline \multirow{2}{*}{ Group } & \multirow{2}{*}{$\mathbf{N}$} & \multicolumn{4}{|c|}{ Paired t-test, $\boldsymbol{\alpha}=\mathbf{5 \%}$} \\
\cline { 3 - 6 } & & Mean & $\mathbf{t}$ & $\mathbf{d f}$ & $\mathbf{p}$ \\
\hline Group-1 & 32 & -54.00 & -49.22 & 31 & .000 \\
\hline Group-2 & 32 & -55.56 & -50.52 & 31 & .000 \\
\hline
\end{tabular}

Table II showed the average of creative thinking skills for groups 1 and 2 are -54.00 and -55.56 and the t score gives $t$ value $=-49.22$ and -50.52 for degrees of freedom $(\mathrm{df})=32$ (groups-1 and group-2). Each score is considered significant, because $\mathrm{p}<5 \%$. Therefore, the $\mathrm{t}$ result of the calculation is negative, so it showed that there is an increase in students' creative thinking skills after the application of OrDP2E learning model based contextual approach all groups.

TABLE III: THE RESULTS OF INDEPENDENT T-TEST OF STUDENTS' CREATIVE THINKING SKILLS IN ALL GROUPS.

\begin{tabular}{|c|c|c|c|}
\hline $\begin{array}{c}\text { Independent t-test, } \boldsymbol{\alpha}= \\
\mathbf{5 \%}\end{array}$ & T & df & Sig. (2-tailed) \\
\hline N-gain_Group-1_Group-2 & .492 & 62 & .486 \\
\hline
\end{tabular}

Table III showed that $\mathrm{t}$ arithmetic gives $\mathrm{t}_{\text {count }}<\mathrm{t}_{\text {table }}$ with significance level $\mathrm{P}>5 \%$. This clearly indicates that there is no differences in the increase of students' creative thinking skills after the implementation of learning with OrDP2E learning model based contextual approach for all groups. Table II explained that there is a significant difference between pre-test and post-test (there is an improvement) of students' creative thinking skills. Table III showed that there is no significant difference in the students' creative thinking skills from the impact of applying the OrDP2E learning model based contextual approach to all groups. This is because it has been developed to improve students' creative thinking skills through syntaxes, e.g. problem orientation, problem definition, hypothesis submission, hypothesis testing, and evaluation. The results are also supported with theoretical and empirical evidences that OrDP2E learning model is a natural science learning model that refers to a contextual approach to train students' creative thinking skills [1] supported by theories of learning; theory of motivation, cognitive-social constructivist theory and cognitive learning theory [14]. This is supported by the results of the study [14-30] that the models, media, methods, instruments are eligible for its validity, practicality and effectiveness will be able to improve and achieve learning objectives. Therefore, the OrDP2E learning model is effective in improving the creative thinking skills of junior high school students. The improvement of students' creative thinking skills is strengthened by the qualitative data presented in Figure 1. 

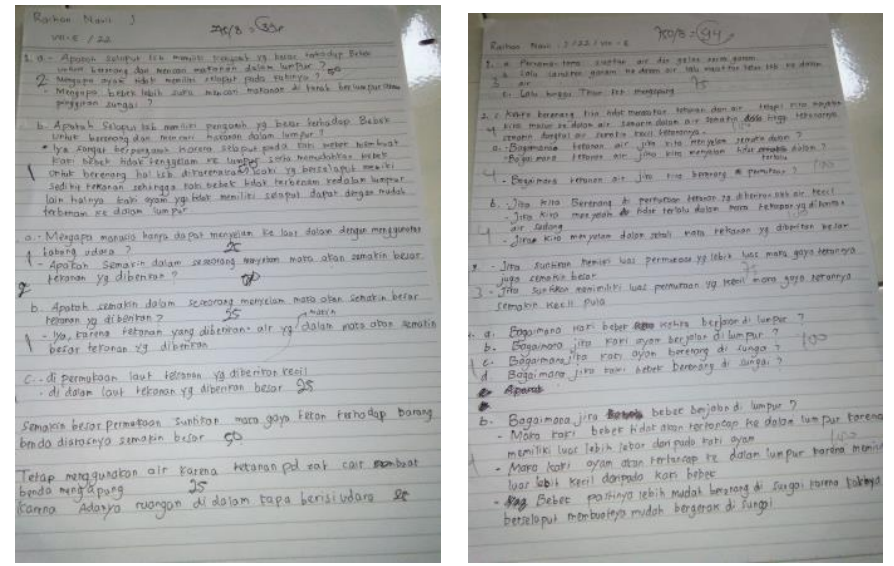

Figure 1. Differences in students' creative thinking skills pre-test and post-test the implementation of the OrDP2E learning model with a contextual approach.

Based on Figure 1, it explained that the students' pre-test score is 34 that ranked as low category. This showed that students' creative thinking skills are still very low. After the students obtained the treatment of OrDeP2E model with contextual approach, students' creative thinking skill is improved, seen from high post-test score is 94 . In pre-test sheet, it could be seen that students lack of understanding in answering questions related to the indicators of creative thinking. After they were given the treatment, they had a better understanding on how to answer the questions based on the indicators of creative thinking. Based on the result, the students could understand the indicators of creative thinking. According to Bruner [8] the learning stage which the students do a direct observation to understand the environment is called enactive, and the learning stage through the process of interpretation or hypotheses about what being observed is called the symbolic stage. In learning using OrDeP2E learning model with contextual approach, students also through enactive and symbolic process which they do direct observation or pass the investigation and do interpretation about what is being observed or make hypothesis. Through the learning phase, students are able to reach the indicator of creative thinking which the indicators make hypothesis and experiment. The Improvement of students' creative thinking skill after the implementation of OrDeP2E learning model with contextual approach supported by student response data presented in Table IV.

TABLE IV: STUDENT RESPONSE TO ORDEP2E LEARNING MODEL WITH CONTEXTUAL APPROACH

\begin{tabular}{|c|c|c|c|}
\hline \multirow{2}{*}{$\begin{array}{c}\text { Student } \\
\text { response }\end{array}$} & \multicolumn{3}{|c|}{ Group (Class VIIIC dan VIIID) } \\
\cline { 2 - 4 } & Sample & Respons & Category \\
\cline { 2 - 4 } & 64 & $85.21 \%$ & Very Positive \\
\hline
\end{tabular}

Table IV showed in general, students responded very positively to the OrDeP2E learning model based on contextual approach and learning instruments. The results of this study become empirical evidence of the effectiveness of the learning model of OrDeP2E based on contextual approach to improve the creative thinking skills of junior high school students.

\section{CONCLUSION}

OrDeP2E study model with contextual approach is natural science learning model which could improve students' creative thinking skill. The research result proved that: 1) There is an improvement of creative thinking skill to junior high student with $\alpha=5 \%$; 2) Average score of n-gain students' creative thinking skill is categorized as high rank; 3) the absence of any significant n-gain consistency of creative thinking skills in all groups; and 4) Students responds are very positively. Therefore, OrDeP2E learning model with contextual approach has been proven effective to improve the creative thinking skill of junior high school students. The implications of this research are as an alternative in improving students' creative thinking skills in Indonesia.

\section{ACKNOWLEDGMENTS}

The author would like to thank the principal of SMPN 1 Krian (Sidoarjao, Indonesia) who has allowed me to conduct the research, as well as the science teachers, eight grade students who have been voluntarily to be the instrument in this research, LPDP and Flores University.

\section{REFERENCES}

[1] M. Panjaitan, M. Nur, \& B. Jatmiko, Jurnal Pendidikan Indonesia, vol. 11(8), 2016.

[2] S. Krulik \& J. A. Rudnick, The New Sourcebook for Teaching Reasoning and Problem Solving in Junior and Senior High School. Boston: Allyn and Bacon, 1996.

[3] S. Munandar \& C. Utami, Pengembangan Kreativitas Anak Berbakat. Jakarta: Rineka Cipta, 2012.

[4] E. Mulyasa, Kurikulum Tingkat Satuan Pendidikan. Bandung : PT. Rosdakarya, 2013.

[5] M. Nur, Berpikir Kreatif. Surabaya: Unesa Press, 2014.

[6] W. Sanjaya, Strategi Pembelajaran Berorientasi Standar Proses Pendidikan. Jakarta: Prenada Media Group, 2010.

[7] B. Joyce, M. Weil \& E. Calhoun, Model of Teaching. New Jersey: Prentice Hall, 2009.

[8] M. Nur, Teori-Teori Pembelajaran Kognitif. Surabaya: Unesa Press, 2008.

[9] A. Winarti, Jurnal Ilmiah JPFK, vol. 1(1), 2015.

[10] H. Doa, Makalah Seminar Hasil. Surabaya: Unesa, 2018.

[11] Prabowo, Metodologi Penelitian. Surabaya: Unesa University Press, 2011.

[12] R. R. Hake, Am. J. Phys., vol. 66(64), 1998.

[13] R. I. Arends, Learning to Teach. New York: Mc. GrawHill Companies, 2012.

[14] N. M. Suyidno, L. Yuanita, B. K. Prahani \& B. Jatmiko, Journal of Baltic Science Education, vol. 17(136), 2018.

[15] F. Erika, B. K. Prahani, Z. A. I. Supardi \& Tukiran, WTE \& TE, vol. 17(179), 2018.

[16] B. K. Prahani, S. W. Winata \& L. Yuanita, Jurnal Penelitian Pendidikan Sains, vol. 4(503), 2015.

[17] B. K. Prahani, M. Nur, L. Yuanita \& I. Limatahu, Vidhya Karya, vol. 31(72), 2016. 
[18] B. K. Prahani, I. Limatahu, S. W. Winata, L. Yuanita, \& M. Nur, International Journal of Education and Research, vol. 4(231), 2016.

[19] B. K. Prahani, N. Suprapto, Suliyanah, N. A. Lestari, M. N. R. Jauhariyah, S. Admoko \& S. Wahyuni, Journal Physics: Conference Series, vol. 997(08), 2018.

[20] B. Jatmiko, B. K. Prahani, Munasir, Z. A. I. Supardi, I. Wicaksono, N. Erlina, P. Pandiangan, R. Althaf \& Zainuddin, Journal of Baltic Science Education, vol. 17(1), 2018.

[21] E. Purwaningsih, S. Suyatno, Wasis, \& B. K. Prahani, Journal Physics: Conference Series, vol. 997(32), 2018.

[22] T. Sunarti, Wasis, Madlazim, Suyidno, \& B. K. Prahani, Journal Physics: Conference Series, vol. 997(13), 2018.

[23] H. Madeali \& B. K. Prahani, Journal Physics: Conference Series, vol. 997(29), 2018.
[24] P. Pandiangan, M. G. I. Sanjaya, \& B. Jatmiko, Journal of Baltic Science Education, vol. 16(651), 2017.

[25] I. Wicakson, Wasis, \& Madlazim, Journal of Baltic Science Education, vol. 16(549), 2017.

[26] Suyidno, M. Nur, L. Yuanita, \& B. K. Prahani, Journal of Research \& Method in Education, vol. 7(56), 2017.

[27] Y. T. Shin, Journal of Distance Education and e-learning, vol. 2(64), 2015.

[28] R. J. Arjunan, IOSR Journal of Humanities and Social Science (JHSS), vol. 6(24), 2012.

[29] M. N. Anwar, Internasional Interdisciplinary Journal of Education, vol. 3(47), 2012.

[30] C. Thomas \& Goran, Journal of Special Education Techonology, vol. 6(92), 2015.

[31] Riduwan, Skala Pengukuran Variabel-Variabel Penelitian. Bandung: AlfaBeta, 2010. 